\title{
Traditional uses of medicinal animals in the semi-arid region of northeastern Brazil
}

\author{
Rômulo Romeu Nóbrega Alves*, Rita Oliveira de Sousa Neta, Dilma Maria de Brito Melo Trovão, \\ Jose Etham de Lucena Barbosa, Adrianne Teixeira Barros and Thelma Lucia Pereira Dias
}

\begin{abstract}
The present work presents an inventory of the traditional medicinal uses of animals in the municipality of Bom Sucesso in Paraíba State (PB) in the semiarid northeastern region of Brazil. Information was obtained through the use of semi-structured interviews with 50 people who use zootherapeutic products. A total of 25 animal species used for medicinal purposes were identified (18 vertebrates and seven invertebrates) distributed among five taxonomic categories; the groups with the largest numbers of citations were: mammals (8 citations), insects (7), and reptiles (5). The most cited animal species were: Tubinambis merianae "teju" lizards (44 citations); Apis mellifera Italian honeybees (318 citations); Gallus gallus chickens (31 citations); Ovis aries sheep (31 citations); Crotalus durissus rattlesnakes (14 citations); Boa constrictor (12 citations); and Bos taurus cattle (12 citations). A significant number of illnesses and conditions treated with animal-based medicines were cited, and the category with the greatest number of citations was "problems affecting the respiratory system". Our results suggest that the use of zootherapeutics in the region is persistent, and that knowledge about these curative practices is an integral part of the regional culture. As such, studies concerning the uses of zootherapeutics are important windows to understanding human/environmental/cultural interactions and a pathway to conciliating regional cultures with efforts to conserve the native fauna.
\end{abstract}

\section{Background}

Humans have always used nature as a source of basic resources for survival, including treatments for infirmities, and human medical practices include the use of plants, animals, and minerals in the production of remedies [1]. Researchers have generally emphasized studies of medicinal plants, relegating medicinal animals a lower priority. Recently, however, investigations of this theme have intensified, reinforcing the idea that the use of medicinal animal resources has long been present in all societies and continues even up to the present day [2-15].

Brazil's high biological and sociocultural diversity $[16,17]$ translates into a wealth of traditional knowledge and practices, including the use of animals for medicinal purposes. It is estimated that Brazil hosts between $15 \%$ and $20 \%$ of the world's biological diversity, and the greatest number of endemic species. Brazil has more than 200 indigenous tribes and a large number of traditional communities that

\footnotetext{
* Correspondence: romulo_nobrega@yahoo.com.br

Departamento de Biologia, Universidade Estadual da Paraíba, Av. das Baraúnas, 351/Campus Universitário, Bodocongó, 58109-753, Campina
} Grande, PB, Brazil all possess considerable knowledge about the local fauna and flora and exhibit an array of natural resource use strategies and each ethnic culture possesses a broad knowledge regarding the medicinal properties of wildlife species $[18,19]$. The extensive medicinal use of animal parts and products has been documented both in rural and urban areas [3,4,6,17-31], and is sustained by a thriving trade in medicinal animals conducted by herbalists in markets throughout Brazil [3,4,17,32].

Studies of the utilization of medicinal animals by human populations living in northeastern Brazil are still relatively scarce, even though the region retains significant cultural and biological diversity that is reflected in a rich popular knowledge about biological medicinal resources [24]. Historically, ethnobiological studies have been largely directed towards ethnobotanical themes, although ethnozoological studies have intensified in recent years [33]. In the specific case of the semiarid region of Paraíba State, studies undertaken in a number of localities [11,30,34-36], have highlighted the cultural importance of using zootherapeutic items for treating human 
as well as animal illnesses and reflect the strong relationship these local populations have with the natural resources available around them $[37,38]$. In an effort to contribute to our knowledge of zootherapeutic practices and their implications in the semiarid region of northeastern Brazil, the present work documented the animals used as zootherapeutics in the municipality of Bom Sucesso in the semiarid region of Paraíba State (PB).

\section{Methods}

The present research was carried out in the municipality of Bom Sucesso (06 26' 42" S; 37 55' 46" W), situated in western Paraíba State in northeastern Brazil (Figure 1). This municipality was created by State Law $\mathrm{N}^{\circ} 3049$ of June 17, 1963, and comprises an area of $198 \mathrm{~km}^{2}$, with a population of 5,280 inhabitants, of which 1,558 live in urban areas and 3,722 in the rural zone.

The municipality of Bom Sucesso is located within the semiarid region known as the Drought Polygon of Brazil. The regional climate is hot and humid, with rainfall in the autumn and winter (classified as AW' by the Koppen system). Paraíba State is divided into bioclimatic regions, and the municipality of Bom Sucesso has a hot and attenuated dry climate, with 7 to 8 months of drought, average yearly temperatures of 27 to $28^{\circ} \mathrm{C}$, and with average annual rainfall of 1,000 $\mathrm{mm}$ (type 4ath-Tropical). The regional vegetation is known as Caatinga (deciduous thorny scrub) and the local topography varies from 270 to $600 \mathrm{~m}$ above sea level. The municipal health infrastructure includes a hospital with 16 beds and three ambulatory units. There are 16 grammar schools and one high school.

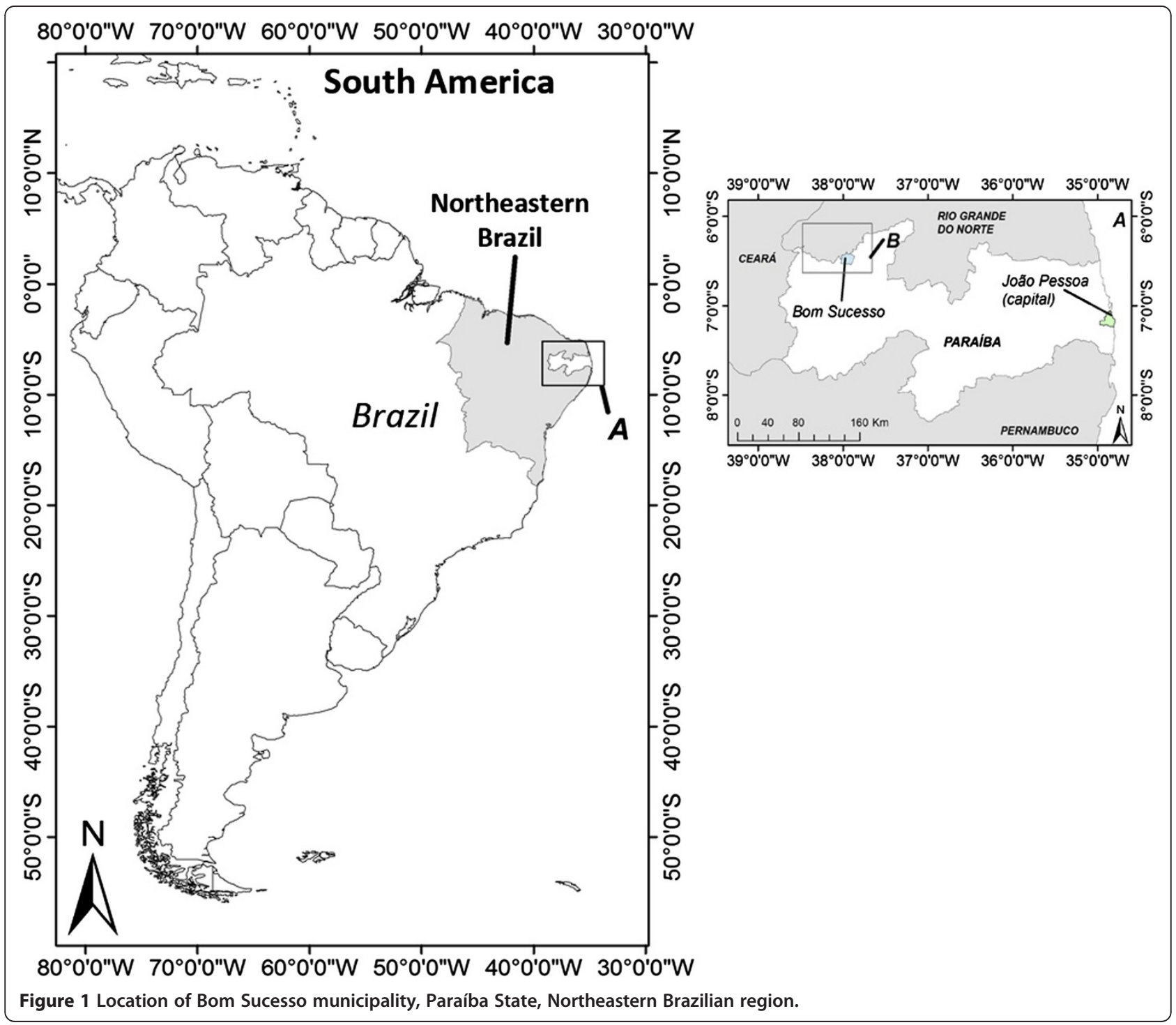


Table 1 Animals species used in popular medicine in the municipality of Bom Sucesso, Paraíba State, Brazil

\begin{tabular}{|c|c|c|c|c|}
\hline Family/species/local name & $\begin{array}{l}\text { Number } \\
\text { of citation }\end{array}$ & Use Value & Part used & Disease (or illness) \\
\hline \multicolumn{5}{|l|}{ INSECTS } \\
\hline \multicolumn{5}{|l|}{ Apidae } \\
\hline $\begin{array}{l}\text { Apis mellifera (Linnaeus, 1758)- } \\
\text { Africanised honey bee, "abelha } \\
\text { italiana" }\end{array}$ & 38 & 0.56 & Honey $(7,8)$ & $\begin{array}{l}\text { Sore throat, flu, shortness of breath, cough, } \\
\text { tuberculosis }\end{array}$ \\
\hline $\begin{array}{l}\text { Partamona cupira (Smith)-a } \\
\text { stingless Bee, "Abelha cupira" }\end{array}$ & 2 & 0.04 & Honey $(7,8)$ & Earache, menstrual cramps \\
\hline $\begin{array}{l}\text { Melipona subnitida (Ducke, } \\
\text { 1910)-jandaíra }\end{array}$ & 12 & 0.16 & Honey $(7,8)$ & Sore throat, flu, earache, hoarseness \\
\hline $\begin{array}{l}\text { Tetragonisca angustula } \\
\text { (Latreille, 1811)-abelha mosquito }\end{array}$ & 6 & 0.10 & Honey $(7,8)$ & Earache, sore throat \\
\hline $\begin{array}{l}\text { Cephalotrigona capitata } \\
\text { (Smith 1854)-Abelha mumbuca }\end{array}$ & 2 & 0.02 & Honey $(7,8)$ & Sore throat, nervous problems \\
\hline \multicolumn{5}{|l|}{ Termitidae } \\
\hline $\begin{array}{l}\text { Nasutitermes macrocephalus } \\
\text { (Silvestri, 1903)-Termite, Cupim }\end{array}$ & 2 & 0.02 & Whole anima (7) & Bronchitis, whooping cough \\
\hline \multicolumn{5}{|l|}{ Unidentified family } \\
\hline Unidentified species-beetle & 1 & 0.02 & Beetle's Nest & Mumps \\
\hline \multicolumn{5}{|l|}{ AMPHIBIANS } \\
\hline \multicolumn{5}{|l|}{ Bufonidae } \\
\hline Rhinella jimi (Stevaux, 2002), Toad & 1 & 0.02 & Abdomen (10) & Erysipelas \\
\hline \multicolumn{5}{|l|}{ REPTILES } \\
\hline \multicolumn{5}{|l|}{ Chelidae } \\
\hline $\begin{array}{l}\text { Phrynops geoffroanus } \\
\text { (Schweigger, 1812)-Geoffroy's } \\
\text { side-necked turtle, "cágado" }\end{array}$ & 5 & 0.06 & Fat (3) & Swelling, sore throat, flu, stuffy nose \\
\hline \multicolumn{5}{|l|}{ Teiidae } \\
\hline $\begin{array}{l}\text { Tupinambis merianae (Duméril \& } \\
\text { Bibron, 1839)-Teju lizard, "tegu", } \\
\text { "tejuaçú" }\end{array}$ & 44 & 0.88 & Fat (3), meat (5) & Sore throat, thrombosis \\
\hline \multicolumn{5}{|l|}{ Crotalidae } \\
\hline $\begin{array}{l}\text { Crotalus durissus Linnaeus, } \\
\text { 1758-South American rattlesnake, } \\
\text { "Cascavel" }\end{array}$ & 14 & 0.22 & Fat (3) & $\begin{array}{l}\text { Rheumatism, skin spots, eye problems, plantar } \\
\text { fasciitis, Swelling, pain in general, hoarseness }\end{array}$ \\
\hline \multicolumn{5}{|l|}{ Boidae } \\
\hline $\begin{array}{l}\text { Boa constrictor (Linnaeus, 1758)- } \\
\text { Boa, Cobra de veado }\end{array}$ & 12 & 0.22 & Fat (3) & $\begin{array}{l}\text { Rheumatism, swelling, herniated intervertebral } \\
\text { disk, bone fractures }\end{array}$ \\
\hline \multicolumn{5}{|l|}{ Tropiduridae } \\
\hline $\begin{array}{l}\text { Tropidurus hispidus (Spix, 1825)- } \\
\text { Lizard, Lagartixa }\end{array}$ & 1 & 0.02 & Whole animal (9) & Sore throat \\
\hline \multicolumn{5}{|l|}{ BIRDS } \\
\hline \multicolumn{5}{|l|}{ Phasianidae } \\
\hline $\begin{array}{l}\text { Gallus gallus domesticus } \\
\text { (Linnaeus, 1758)-chicken, Galinha }\end{array}$ & 31 & 0.38 & $\begin{array}{l}\text { Gizzard (5), fat ( } 3 \text { or } 8) \text {, } \\
\text { eggshells ( } 2) \text {, egg yolk (6), } \\
\text { meat (5) }\end{array}$ & $\begin{array}{l}\text { Indigestion, sinusitis, shortness of breath, bronchitis, } \\
\text { nervous problems, rheumatism, stuffy nose, weak } \\
\text { bones, flu, weakness, sore throat, furuncle }\end{array}$ \\
\hline \multicolumn{5}{|l|}{ Meleagrididae } \\
\hline Numida meleagris Linnaeus, & 2 & 0.04 & Meat (5) & whooping cough \\
\hline
\end{tabular}




\begin{tabular}{|c|c|c|c|c|}
\hline \multicolumn{5}{|l|}{$\overline{\text { Anatidae }}$} \\
\hline $\begin{array}{l}\text { Anas platyrhynchos Linnaeus, } \\
1758 \text {-Duck, Pato }\end{array}$ & 1 & 0.02 & Eggs (5) & Weakness \\
\hline \multicolumn{5}{|l|}{ Corvidae } \\
\hline $\begin{array}{l}\text { Cyanocorax cyanopogon } \\
\text { (Wied-Neuwied, 1821)- } \\
\text { White-naped Jay }\end{array}$ & 1 & 0.02 & Gizzard (5) & Asthma \\
\hline \multicolumn{5}{|l|}{ MAMMALS } \\
\hline \multicolumn{5}{|l|}{ Trichechidae } \\
\hline $\begin{array}{l}\text { Trichechus manatus } \\
\text { (Linnaeus, 1758)-Manatee, } \\
\text { Peixe-boi }\end{array}$ & 3 & 0.02 & Fat (3) & Headache, rheumatism, corporal lesions \\
\hline \multicolumn{5}{|l|}{ Canidae } \\
\hline $\begin{array}{l}\text { Canis lupus (Linnaeus, 1758)- } \\
\text { Domestic dog, Cachorro }\end{array}$ & 1 & 0.02 & Faeces (1) & Measles \\
\hline \multicolumn{5}{|l|}{ Dasypodidae } \\
\hline $\begin{array}{l}\text { Dasypus novemcinctus } \\
\text { (Linnaeus, 1758)-Nine-banded } \\
\text { armadillo, Tatu-verdadeiro }\end{array}$ & 2 & 0.04 & Meat (5), tail (4) & Back ache, snake bite \\
\hline \multicolumn{5}{|l|}{ Mustelidae } \\
\hline $\begin{array}{l}\text { Conepatus semistriatus } \\
\text { (Boddaert, 1785)-Striped } \\
\text { hog-nosed skunk, "Ticaca" }\end{array}$ & 1 & 0.02 & Meat (5) & Rheumatism \\
\hline \multicolumn{5}{|l|}{ Caviidae } \\
\hline $\begin{array}{l}\text { Kerodon rupestris (Wied-Neuwied, } \\
\text { 1820)-Rock cavy, "Mocó" }\end{array}$ & 3 & 0.04 & Meat (5) & $\begin{array}{l}\text { Disorders after parturition (to accelerate recovery } \\
\text { after parturition), weakness, thrombosis }\end{array}$ \\
\hline \multicolumn{5}{|l|}{ Bovidae } \\
\hline $\begin{array}{l}\text { Bos taurus Linnaeus, } \\
\text { 1758-Domestic cattle, "Boi" }\end{array}$ & 12 & 0.20 & $\begin{array}{l}\text { Liver }(5) \text {, horn }(1,7) \text {, } \\
\text { marrow }(7) \text {, milk }(8) \text {, } \\
\text { urine }(8) \text {, butter }(8) \text {, hoof } \\
\text { proteins }(7)\end{array}$ & $\begin{array}{l}\text { Anaemia, the evil eye, nervous problems, whooping } \\
\text { cough, weakness, eye problems, sore throat, baldness, } \\
\text { tuberculosis }\end{array}$ \\
\hline $\begin{array}{l}\text { Ovis aries Linnaeus, 1758-Sheep, } \\
\text { "Carneiro" }\end{array}$ & 31 & 0.36 & Fat (4), suet (4) & $\begin{array}{l}\text { Rheumatism, cracks in the sole of the feet } \\
\text { inflammations, swelling, nervous problems, furuncle, } \\
\text { one fractures, suck a splinter out of skin or flesh, } \\
\text { mycosis }\end{array}$ \\
\hline \multicolumn{5}{|l|}{ Hydrochaeridae } \\
\hline $\begin{array}{l}\text { Hydrochoerus hydrochaeris } \\
\text { (Linnaeus, 1766), capybara, } \\
\text { capivara }\end{array}$ & 1 & 0.02 & $\mathrm{Fa}(3)$ & Osteoporosis \\
\hline
\end{tabular}

\section{Procedures}

Field research was conducted from December 2007 to February 2008. During the first contacts with the local population, we attempted to identify local people with a specialized knowledge of medicinal animal use, following Alves and Rosa [20]. A specialist is defined as "a person recognized by the community as having deep knowledge about the use of animals in manufacturing remedies and in promoting cures". Information on the use of animal in traditional medicines was collected through interviews with 50 persons ( 11 men and 39 women), mainly from the elderly people, who still retain the major portion of traditional knowledge in their respective communities. Additional interviewees were chosen by using the snowball technique, based on information initially provided by the specialists. Interviews were conducted on a oneto-one basis. Prior informed consent was obtained for all interviews conducted.

Data were gathered through interview-questionnaires, with some questions left open-ended [39]. Questionnaires encompassed the following aspects: local name of the animal used as remedy; parts used as medicine; conditions treated with the remedy; preparation and usage; restrictions of use; spiritual aspects linked to the use; use 


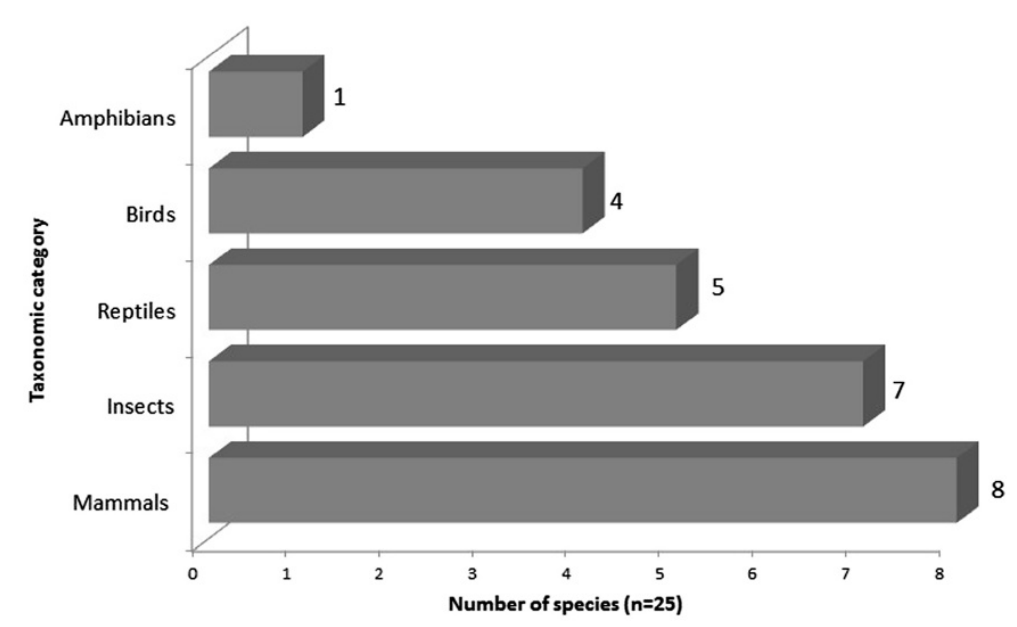

Figure 2 Animal species used as remedies by taxa in Bom Sucesso, Paraíba State, Northeastern Brazil.

of live or dead animals; how animals were obtained; storage conditions; collection sites; efficacy of the remedies; traditional uses of the remedies in the community; how knowledge was acquired by the interviewees; reliance on animal-based remedies; why the interviewee used animal-based remedies.

The ethical approval for the study was obtained from the Ethics committee of Paraiba University State. To respect intellectual property rights, we adopted the following protocol in the field: before the survey, we introduced ourselves, explained the nature and objectives of our research and asked the respondents for permission to record the information.

Species' vernacular names were recorded as quoted by interviewees. Zoological material was identified with the aid of specialists, through (1) examination of voucher specimens donated by the interviewees; (2) photographs of the animals or their parts, taken during interviews; (3) vernacular names, with the aid of taxonomists familiar with the study areas' fauna. Voucher specimens and/or photographs were deposited at the Department of Systematics and Ecology, Federal University of Paraíba.

\section{Data analysis \\ Use value}

For each species was calculated the use value (adapted from the proposal of Phillips et al. [40], a quantitative method that demonstrates the relative importance of species known locally. These value was calculated using the following formula: $\mathrm{UV}=\Sigma \mathrm{U} / \mathrm{n}$, where: $\mathrm{UV}=$ use value of a species; $U=$ number of citations per species; $\mathrm{n}=$ number of informants.

Application of the use-value of each species is based objectively on the importance attributed by the informants and does not depend on the opinion of the researcher.

\section{Results and discussion}

A total of 25 medicinal animals were cited by the interviewees (21 vertebrates and seven invertebrates). These species inventoried include five taxonomic groups: mammals ( 8 species), insects (7 species), birds (4 species), reptiles ( 5 species), and amphibians (1 species) belonging to 19 families (Table 1 and Figure 2).

The most cited animal species were: Tubinambis merianae (Duméril \& Bibron, 1839 (Figure 3)) "teju" lizards (44 citations); Apis mellifera (Linnaeus, 1758) Italian honeybees (28 citations); Gallus gallus (Linnaeus, 1758) chickens (19 citations); Ovis aries (Linnaeus, 1758) sheep (17 citations); Crotalus durissus (Linnaeus, 1758) rattlesnakes (11 citations); Boa constrictor (11 citations); and Bos taurus (Linnaeus, 1758) cattle (10 citations).

As has been seen in other studies of zootherapeutics undertaken in Brazil [41] many animals had multiple

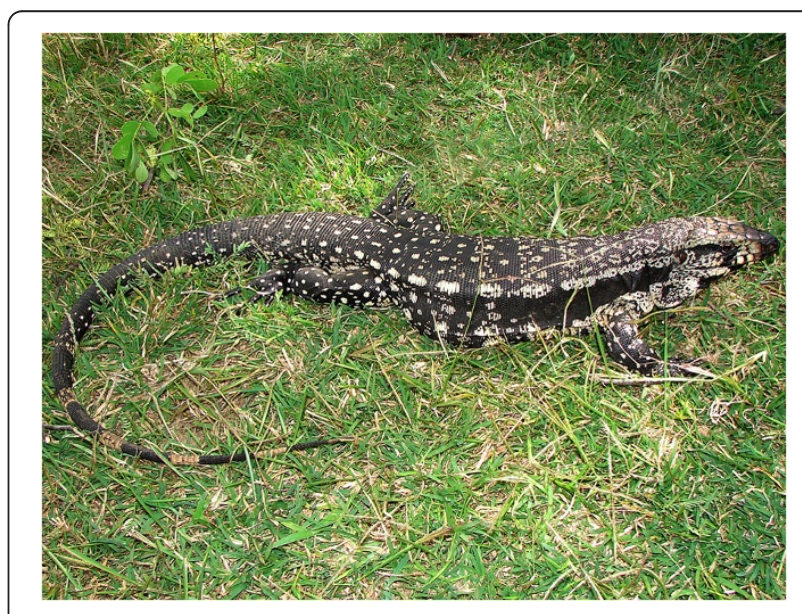

Figure 3 Tubinambis merianae, the most important medicinal animal in the municipality of Bom Sucesso, Paraíba State, Brazil. 
medicinal uses, such as: cattle (Bos taurus), whose body parts (liver, urine, butter, marrow, hoof proteins) are used to treat illnesses such as sore throats, anemia, and severe coughing (whooping cough), and; chickens (Gallus domesticus), whose body parts (fat, gizzard, eggs [shells and yolks], and meat) are used to treat sinus problems, shortness of breath, indigestion, bronchitis, stuffy nose, rheumatism, weak bones, colds, general weakness, sore throats, hoarseness, and boils. Among the species with multiple therapeutic indications are Apis mellifera, Ovis aries, and Crotalus durissus.

The accessibility and availability of local faunal resources influence the choices of the zootherapeutics utilized, so that the majority of the medicinal animals used occur within the research area. The commerce of zootherapeutic items in public markets is very common in many Brazilian towns and cities $[4,5,7,32,42,43]$, which results in additional pressure on useful species, although the results of our interviews indicated that relatively few people in the region bought their zootherapeutic items, being able to obtain these substances from animals captured and/or kept near their homes.

The medicinal animals cited in this survey were used to treat 43 different illnesses and maladies (Table 1). The treatment categories with the largest number of citations were: problems affecting the respiratory apparatus and illnesses of the osteomuscular system - which corroborates the results of other research projects that have examined the use of zootherapeutics. Alves and Rosa [20] demonstrated that problems affecting the respiratory system and the osteomuscular system and connective tissues always appeared as the most cited in investigations of home-remedy uses in northern and northeastern Brazil. Costa-Neto [26] likewise found that animal-based medicines are frequently used to treat respiratory diseases in Bahia State, in northeastern Brazil. Similar results were reported by Silva et al. [44] in a survey of public markets in the city of Recife in Pernambuco State (also in the northeastern region of that country).

Home remedies are obtained from whole animals, or their body parts, or products extracted from them, such as fat, honey, milk, butter, wax, urine, feces, meat, skin, bones, liver, tails, gizzards, and eggs. Among these products, animal fat was the most cited in this and in other studies [2,5-7,14,18,20,25,32,35]. Most of these materials have been reported in other surveys of human utilization of zootherapeutic resources in Brazil $[14,24,45]$, indicating that these practices are widely disseminated throughout the country.

The zootherapeutic resources identified in the present study demonstrated Use-values (VU) that varied from 0.02 to 0.88 . Most of the species surveyed had low VU values, with $67 \%$ percent of them being below 0.10 (Table 1). These data indicates considerable variation in species uses, with some species being frequently utilized and therefore more important in traditional local medicine. The species having the greatest use-values were Tupinambis merianae ( $\mathrm{VU}=0.88)$, Apis mellifera (VU = 0.56), and Gallus domesticus $(\mathrm{VU}=0.38)$, and all three are known to be widely used in traditional medicine throughout Brazil $[14,24,45]$.

One important aspect of the use of medicinal animals is related to public health $[15,20]$. In the present study, which involved many home visits, we witnessed inappropriate storage of many products and only minimal considerations of hygiene. These lax storage practices did not seem to concern most of the people using these materials, and they demonstrated a lack awareness of the possible grave health consequences of inadequate storage of zootherapeutics (or any other product used for medicinal purposes). In their research on zootherapy in northern and northeastern Brazil, Alves and Rosa [32], likewise observed a general lack of concern for the storage conditions of zootherapeutic products and the risks of bacterial contamination, and Alves and Rosa [15] recommended the implementation of sanitary measures to govern the use and storage of these folk medicines in light of possible negative effects on public health.

Our results indicated that the use of animals for medicinal purposes in the community studied was quite accentuated, and that these people retain considerable knowledge about the local fauna used in health care treatments. It was also seen that zootherapeutics are most frequently used to treat the common illnesses in the population, such as problems affecting the respiratory apparatus (including throat inflammations, coughing, colds, and asthma). Popular knowledge about these curative practices is an integral part of the regional culture and demonstrates the necessity of carefully studying zootherapeutic practices to better understand human/environmental/cultural interactions - especially in light of the probable existence of valuable pharmacologically active substances in these remedies and the opportunity to conciliate the regional culture with animal conservation efforts.

The results obtained in the present research, together with data provided by other workers, confirm that the medicinal uses of animals represent ethnozoological connections of relevant cultural value in the semiarid region of northeastern Brazil. Additional studies will be necessary to amplify our knowledge of the regional medicinal fauna from a historical perspective and examine the interwoven cultural, pharmacological, and ecological interdependencies of zootherapeutic practices in traditional cultures.

\section{Competing interests}

The authors declare that they have no competing interests. 


\section{Authors' contributions}

RRNA, ROSN, DMBMT, JEL, ATB and TLPD-Writing of the manuscript, literature survey and interpretation; RRNA and ROSN-Ethnozoological data, and analysis of taxonomic aspects. All authors read and approved the final manuscript.

\section{Acknowledgments}

The first author would like to acknowledge to CNPq (Conselho Nacional de Desenvolvimento Científico e Tecnológico) for providing a research fellowship. The authors would like to acknowledge to CNPq/Edital Universal program (472623/2009-5 and 486005/2011-9) and to UEPB/PROPESQ (2008 and 2011) for financial support. Special thanks are due to all interviewees, who kindly shared their knowledge with us.

Received: 15 August 2012 Accepted: 7 October 2012

Published: 10 October 2012

\section{References}

1. Alves RRN, Rosa IL: Animals in Traditional Folk Medicine: Implications for Conservation. Berlin Heidelberg: Springer; 2012.

2. Alves RRN: Relationships between fauna and people and the role of ethnozoology in animal conservation. Ethnobiology and Conservation 2012, 1:1-69.

3. Alves RRN, Oliveira MGG, Barboza RRD, Lopez LCS: An ethnozoological survey of medicinal animals commercialized in the markets of Campina Grande, NE Brazil. Hum Ecol Rev 2010, 17:11-17.

4. Oliveira ES, Torres DF, Brooks SE, Alves RRN: The medicinal animal markets in the metropolitan region of Natal City, Northeastern Brazil. J Ethnopharmacol 2010, 130:54-60.

5. Ferreira FS, Albuquerque UP, Coutinho HDM, Almeida WO, Alves RRN: The trade in medicinal animals in Northeastern Brazil. eCAM 2012, 2012:1-20.

6. Ferreira FS, Brito S, Ribeiro S, Almeida W, Alves RRN: Zootherapeutics utilized by residents of the community Poco Dantas, Crato-CE, Brazil. J Ethnobiol Ethnomed 2009, 5:21.

7. Ferreira FS, Brito S, Ribeiro S, Saraiva A, Almeida W, Alves RRN: Animalbased folk remedies sold in public markets in Crato and Juazeiro do Norte, Ceara, Brazil. BMC Complement Altern Med 2009, 9:17.

8. Alves RRN, Souto WMS, Barboza RRD: Primates in traditional folk medicine: a world overview. Mammal Rev 2010, 40:155-180.

9. Barboza RRD, Souto WMS, Mourão JS: The use of zootherapeutics in folk veterinary medicine in the district of Cubati, Paraíba State, Brazil. J Ethnobiol Ethnomed 2007, 3:14.

10. Souto W, Mourao JS, Barboza RRD, Alves RRN: Parallels between zootherapeutic practices in Ethnoveterinary and Human Complementary Medicine in NE Brazil. J Ethnopharmacol 2011, 134(3):753-767.

11. Souto WMS, Mourão JS, Barboza RRD, Mendonca LET, Lucena RFP, Confessor MVA, Vieira WLS, Montenegro PFGP, Lopez LCS, Alves RRN: Medicinal animals used in ethnoveterinary practices of the'Cariri Paraibano', NE Brazil. J Ethnobiol Ethnomed 2011, 7:30.

12. Souto WMS, Mourão JS, Barboza RRD, Rocha MSP, Alves RRN: Animal-based medicines used in ethnoveterinary practices in the semi-arid region of Northeastern Brazil. An Acad Bras Cienc 2012, 84(3):669-678.

13. Alves RRN, Alves HN: The faunal drugstore: Animal-based remedies used in traditional medicines in Latin America. J Ethnobiol Ethnomed 2011, 7:9.

14. Alves RRN, Rosa IL, Santana GG: The role of animal-derived remedies as complementary medicine in brazil. Bioscience 2007, 57:949-955.

15. Alves RRN, Rosa IL: Why study the use of animal products in traditional medicines? J Ethnobiol Ethnomed 2005, 1:1-5.

16. Elisabetsky $\mathrm{E}$, Wannmacher $\mathrm{L}$ : The status of ethnopharmacology in Brazil. J Ethnopharmacol 1993, 38:129-135.

17. Alves RRN, Rosa IL: Zootherapy goes to town: the use of animal-based remedies in urban areas of NE and N Brazil. J Ethnopharmacol 2007, 113:541-555.

18. Alves RRN, Rosa IL: Zootherapeutic practices among fishing communities in North and Northeast Brazil: a comparison. J Ethnopharmacol 2007 111:82-103.

19. Alves RRN: Animal-based remedies as complementary medicine in Brazil. Forsch Komplementmed 2008, 15:226-227.

20. Alves RRN, Rosa IL: From cnidarians to mammals: the use of animals as remedies in fishing communities in NE Brazil. J Ethnopharmacol 2006, 107:259-276.
21. Alves RRN, Pereira-Filho GA, Lima YCC: Snakes used in ethnomedicine in Northeast Brazil. Environ Dev Sustainability 2007, 9:455-464.

22. Alves RRN, Pereira Filho GA: Commercialization and use of snakes in North and Northeastern Brazil: implications for conservation and management. Biodivers Conserv 2007, 16:969-985.

23. Alves RRN, Rosa IL: Use of Tucuxi Dolphin Sotalia fluviatilis for medicinal and magic/religious purposes in North of Brazil. Hum Ecol 2008, 36:443-447.

24. Alves RRN: Fauna used in popular medicine in Northeast Brazil. J Ethnobiol Ethnomed 2009, 5:1-30.

25. Alves RRN, Neto NAL, Brooks SE, Albuquerque UP: Commercialization of animal-derived remedies as complementary medicine in the semi-arid region of Northeastern Brazil. J Ethnopharmacol 2009, 124:600-608.

26. Costa-Neto EM: Healing with animals in Feira de Santana City, Bahia, Brazil. J Ethnopharmacol 1999, 65:225-230.

27. Figueiredo N: Os 'bichos' que curam: os animais e a medicina 'folk' em Belém do Pará. Boletim do Museu Paraense Emílio Göeldi 1994, 10:75-91.

28. Silva AL: Animais medicinais: conhecimento e uso entre as populações ribeirinhas do rio Negro, Amazonas, Brasil. Boletim do Museu Paraense Emílio Göeldi 2008, 3:343-357.

29. Branch L, Silva MF: Folk medicine in Alter do Chão, Pará, Brasil. Acta Amazônica 1983, 13:737-797.

30. Confessor MVA, Mendonca LET, Mourao JS, Alves RRN: Animals to heal animals: ethnoveterinary practices in semi-arid region, Northeastern Brazil. J Ethnobiol Ethnomed 2009, 5:37.

31. Almeida CFCBR, Albuquerque UP: Uso e conservação de plantas e animais medicinais no Estado de Pernambuco (Nordeste do Brasil): um estudo de caso. Interciencia 2002, 27:276-285.

32. Alves RRN, Rosa IL: Trade of animals used in Brazilian traditional medicine: trends and implications for conservation. Hum Ecol 2010, 38:691-704.

33. Alves RRN, Souto WMS: Ethnozoology in Brazil: current status and perspectives. J Ethnobiol Ethnomed 2011, 7:22.

34. Souto WMS, Alves RRN, Confessor MVA, Barboza RRD, Mourão JS, Mendonça LET: A Zooterapia na Etnoveterinária do semi-árido paraibano. In A Etnozoologia no Brasil: Importância, Status atual e Perspectivas. Volume 7. 1st edition. Edited by Alves RRN, Souto WMS, Mourão JS. Recife, PE: NUPEEA; 2010:423-446.

35. Alves RRN, Barbosa JAA, Santos SLDX, Souto WMS, Barboza RRD: Animalbased Remedies as Complementary Medicines in the Semi-arid Region of Northeastern Brazil. eCAM 2011, 2011:179876.

36. Alves RRN, Gonçalves MBR, Vieira WLS: Caça, uso e conservação de vertebrados no semiárido Brasileiro. Trop Conserv Sci 2012, 5:394-416.

37. Alves RRN, Mendonça LET, Confessor MVA, Vieira WLS, Lopez LCS: Hunting strategies used in the semi-arid region of northeastern Brazil. J Ethnobiol Ethnomed 2009, 5:12.

38. Barbosa JAA, Nobrega VA, Alves RRN: Hunting practices in the semiarid region of Brazil. Indian J Traditional Knowledge 2011, 10:486-490.

39. Huntington HP: Using traditional ecological knowledge in science: methods and applications. Ecol App/ 2000, 10:1270-1274.

40. Phillips O, Gentry AH, Reynel C, Wilkin P, Galvez-Durand BC: Quantitative ethnobotany and amazonian conservation. Conserv Biol 1994, 8:225-248

41. Costa-Neto EM, Alves RRN: Estado da arte da zooterapia popular no Brasil. In Zooterapia: Os Animais na Medicina Popular Brasileira. Volume 2. 1st edition. Edited by Costa-Neto EM, Alves RRN. Recife, PE: NUPEEA; 2010:13-54.

42. Alves RRN: O comércio de recursos zooterápicos. In Zooterapia: Os Animais na Medicina Popular Brasileira. Volume 2. 1st edition. Edited by Costa-Neto EM, Alves RRN. Recife, PE: NUPEEA; 2010:159-176.

43. Alves RRN, Lima HN, Tavares MC, Souto WMS, Barboza RRD, Vasconcellos A: Animal-based remedies as complementary medicines in Santa Cruz do Capibaribe, Brazil. BMC Complement Altern Med 2008, 8:44.

44. Silva MLV, Alves ÂGC, Almeida AV: A zooterapia no Recife (Pernambuco): uma articulação entre as práticas e a história. Biotemas 2004, 17:95-116.

45. Costa-Neto EM, Alves RRN: Zooterapia: Os Animais na Medicina Popular Brasileira. 1st edition. Recife, PE: NUPEEA; 2010.

\section{doi:10.1186/1746-4269-8-41}

Cite this article as: Alves et al.: Traditional uses of medicinal animals in the semi-arid region of northeastern Brazil. Journal of Ethnobiology and Ethnomedicine 2012 8:41. 